\title{
HISTORY OF PHILOSOPHY
}

\section{DOI https://doi.org/10.30525/978-9934-26-181-7-27}

\section{ДЕФІНІЦІЯ КУЛЬТУРИ У ФІЛОСОФІЇ В. ВІНДЕЛЬБАНДА}

\author{
Брагіна Т. М. \\ кандидат філософських наук, \\ дочент кафедри народної хореографії
}

Білик О. М.

доктор педагогічних наук, дочент кафедри мистецтвознавства і гуманітаристики Харківська державна академія культури

Брагін Ю. А.

кандидат культурологіï, дочент кафедри ЮНЕСКО та соиіального захисту Харківський державний біотехнологічний університет м. Харків, Украӥна

Установлення розмежування між природничими науками і науками про культуру стало центральною темою досліджень основоположника Баденської школи В. Віндельбанда. Підкреслюючи свою принципово критичну філософську позицію, він переглядають деякі положення учення I. Канта. У пошуку нових стимулів руху думки засновники школи звертаються до філософії Й. Г. Фіхте. Його розуміння задачі філософії як установлення системи телеологічно необхідних дій розуму повністю відповідає їх концепції. За В. Віндельбандом, фіхтевська концепція нормативної свідомості як телеологічної системи містить у собі помилку. Вона полягає в утвердженні можливості дедукувати із одного визначення мети засоби до іiі виконання. Це спонукає автора до створення протиріч, вирішення яких повинно рухати свідомість уперед. Тому критичний метод перетворюється у Й. Г. Фіхте на метод діалектичний, який, як і будь-яка дедукція, нездатний вивести із одного принципу все багатоманіття особливого. Телеологічна конструкція «потребує не тільки визначення мети, але і уваги до матеріалу, з допомогою якого ця мета повинна бути здійснена» [1, с. 227-228]. 
У відповідності до позиції критицизму філософія може «установити норми, тільки керуючись дослідом». Тому для загальнозначущого визначення норм філософія повинна спиратися на емпіричний матеріал, який міститься «у фактичному процесі індивідуального і соціального духовного життя» [1, с. 230]. При цьому обгрунтування норм лежить у них самих, у їх телеологічному значенні.

На думку В. Віндельбанда, головним джерелом даних для філософського дослідження є емпірична психологія. Як i учення В. Дільтея, що встановлює зв'язок факту, закону і правила, філософія В. Віндельбанда запозичує від психології «потрійний поділ психічних функцій», який відповідає числу філософських дисциплін. Однак норми у філософії В. Віндельбанда не спираються на поняття психології, а лише усвідомлюються 3 їх допомогою. Отож, виведення всіх результатів із єдиного принципу неможливе: «Від діалектики філософія повинна повернутися до критичного методу» [1, с. 230, 231].

Критицизм повинен дати свою версію розвитку системи філософського знання, що заснована на опозитності матеріалу і форми. Тому у відповідності до обраної раціоналістичної позиції, В. Віндельбанд починає розгляд філософії культури з визначення іiі двох граничних понять, що передбачають можливість розташування між ними множини проміжних визначень. 3 одного боку, філософія культури може ставити задачу визначення ідеалу майбутньої культури. 3 іншого, - вона може зосередитися на розумінні історично даної культури. При цьому ідеальна культура залежить від розуміння культури даної. Сила цієї залежності прямо пропорційна різкості контрасту «між ідеалом і минулими або теперішніми умовами» [2, с. 7]. Напруга між полюсами опозитності задає мисленну установку на майбутній розвиток даного.

Саме філософське розуміння наявного стану культури приводить до передбачення іiі майбутнього розвитку, оскільки, будучи включеним у історичний рух і зрозуміле як член ряду, що розвивається, воно завжди указує на майбутній момент. Протиріччя заданого і даного закладене у будь-якому розумінні філософії культури і перебуває у зв'язку з принциповими особливостями філософсько-історичного методу.

При цьому В. Віндельбанд відмовляється від розгляду історичного розвитку за зразком математичного чи понятійного розвитку: коли знання закону ряду робить можливим побудову його наступних членів. В. Віндельбанд убачає специфічну сутність історичного розвитку в «прогресуючому оформленні часово-фактичного процесу становлення, що не може бути визначеним у поняттях». У цьому випадку розуміння сучасного може привести «лише до визначення задач майбутньої 
культури», а впевненість у їх здійсненні «буде уже справою не пізнання, а переконання і світогляду». Теоретичний розум визначає орієнтири, реалізація яких у дійсності $є$ прерогативою розуму практичного.

Таким чином, В. Віндельбанд розглядає історичний розвиток культури як раціональну проекцію, що виходить із принципового дуалізму понять реального й ідеального. Тому філософія культури $є$ «абстрактною наукою, що оперує 3 допомогою понять». Вона починається там, де закінчується психологічне чи історичне установлення фактичного змісту; вона «відповідає на quaestio juris, причому керується однією лише точкою зору іманентної предметної необхідності» [2, с. 8].

Однак цю формулу розвитку не слід розуміти як установлення закону руху реальності. На думку Г. Зіммеля, вона «виражає відношення духа до дійсності як розвиток, що уходить у безконечність». Тому тут ідеться не про формулювання закону розвитку предмету, а про розуміння розвитку, що виражає смисл методу. Посередництвом нього у науках про культуру встановлюється зв'язок між судженням факту і апріорними положеннями, що складають полюси пізнавального процесу. Як підкреслює Г. Зіммель, кожне окреме судження досліду «перебуває на шляху від однієї крайності до іншої» [3, с. 33, 34].

Тут В. Віндельбанд і Г. Зіммель слідують за І. Кантом, який передає пізнавальну цінність «з'єднанню апріорних положень із суб'єктивновипадковим чуттєвим образом, з'єднанню, право якого слідує як би «гіршій стороні» і наслідує замість досконалості можливість розвитку».

На думку Г. Зіммеля, історичний розвиток культури набуває смислу у міру руху до ідеалу абсолютної досконалості. Цей ідеал є сенсом речей, який «не виступає із них як метафізична дійсність», а «має значущість тільки як ланка розвитку, що виводить за нього самого». Тому ідея розвитку, як регулятивне поняття, звільняє нас «як від пустого ідеалізму, так і від резин'юючого натуралізму» [3, т. 1, с. 135,134$]$.

Ідея розвитку відіграє регулятивну функцію, вона $є$ продуктом розуму. Система критицизму набуває у потрактуванні В. Віндельбанда вигляду «всеохоплюючої філософії культури». При цьому він має на увазі не форму постановки теоретичної проблеми І. Кантом, а «живий плід його учення і його значення для духовного життя теперішнього часу» [2, с. 8]. Результатом кантівської критики було виявлення розумних засновків, які фундують основні галузі культури: науковий розум, мораль, естетичну творчість.

На думку автора, велику роль у філософії культури відіграло відкриття I. Кантом синтетичної свідомості. В. Віндельбанд наділяє принциповою важливістю метод раціоналістичного конструювання дійсності, обсяг 
наукової застосовності якого включає у себе ідею розвитку, що формується логічно із протиставлення заданого і даного.

Значущість абстрактних принципів ставиться вище достовірності конкретного історичного розуму. 3 точки зору В. Віндельбанда, осягнення історичного розуму вимагає «не тільки знання історії, але і знання розуму». Тому критика історичного розуму потребує масштабу. Оскільки цей масштаб повинен бути «масштабом оцінки», а не шкалою кількісного виміру, вихідним у пізнанні історичного розвитку $є$ практичний розум $[1$, c. 223, 224]. Позиція Баденської школи утверджує примат практичного розуму як такого і робить його фундаментом розуму теоретичного.

За В. Віндельбандом, структура предмету і формальність мислення примусили I. Канта до застосування відкритого ним для обгрунтування науки принципу синтезу до інших галузей культури. Так діяльність розуму пронизує практичну і естетичну творчість людини. Критицизм, який виник як усвідомлення проблем науки, набуває значення філософії культури: «В усвідомленні творчого синтезу культура пізнала саму себе, бо у глибинній сутності вона і $\epsilon$ не що інше, як цей творчий синтез» [2, c. 14].

Однак, якщо для розуміння цінності теоретичної культури виявилось необхідним застосовувати категорії, обмеживши їх значущість дослідно даним, то у практичній філософії І. Кант іде зворотнім шляхом. У дослідженні теоретичного розуму він від споглядання піднімається до загальних категорій. Розгляд практичного розуму він починає з закону чистої волі, з якого згодом дедукує окремі обов'язки. Тому В. Віндельбанд у такий спосіб визначає методичний принцип трансцендентальної філософії: «спочатку необхідно виявити загальнозначущі засновки розумової діяльності, на яких... грунтується все те, що ми називаємо культурою, потім 3 допомогою предметного аналізу встановити, які з цих засновків визначаються специфічними емпіричними умовами: отриманий залишок буде таким чином містити у собі одну тільки всезагальну надемпіричну необхідність самого розуму» [2, с. 11]. Це абсолютне апріорі, що має безумовну значущість, входячи в емпіричну свідомість, стає нормою для суб'єкта, що здійснює пізнання.

Під культурою В. Віндельбанд розуміє «сукупність усього того, що людська свідомість у силу притаманної їй розумності виробляє із даного ій матеріалу» [2, с. 12]. При цьому у даному, оскільки воно представляє собою загальнозначущий дослід, уже присутній трансцендентальний синтез у відповідності до надемпіричних предметно значущих форм розуму. Ця діяльність розуму, що відтворює світ із закону інтелекту, заключає «предметну єдність трансцендентального ідеалізму як філософії 
культури». Диференційована культура не може бути представлена як ціле шляхом простого складання іiї окремих життєвих змістів. У життєвому процесі дані лише культурні фрагменти, ціле яких підлягає раціональному формуванню.

\title{
Література:
}

1. Виндельбанд В. Прелюдии. Избранное. Дух и история. Москва: Юрист, 1995. С. 20-293.

2. Виндельбанд В. Философия культуры и трансцендентальный идеализм. Культурология. ХХ век: Антология. Москва: Юрист, 1995. C. $57-68$.

3. Зиммель Г. Избранное: В 2 т. Москва: Юрист, 1996. Т. 1. Философия культуры. 671 с.

\section{DOI https://doi.org/10.30525/978-9934-26-181-7-28}

\section{ЦІЛІСНІСТЬ - ГОЛОВНА ПРОБЛЕМА БОГОСЛОВ’Я КУЛЬТУРИ МИКОЛИ БЕРДЯЄВА}

\author{
Горбань В. М. \\ магістрантка кафедри богослов'я \\ Івано-Франківська академія Івана Золотоустого \\ м. Івано-Франківськ, Україна
}

Проблематика богослов'я культури Бердяєва охоплює чимале коло питань, проте усі вони так чи інакше зумовлені втратою первинної цілісності творіння. Відновлення цілісності світу та його преображення на засадах екзистенційного персоналізму та активно-творчої есхатології стали визначальною інтенцією філософсько-релігійної думки мислителя та були пов'язані з глибоким осмисленням причин і наслідків антропологічної кризи, яка триває понад століття і стає дедалі небезпечнішою для людства. Оскільки попередження, зроблені Бердяєвим на грунті створеної ним профетичної філософії-мудрості, справдилися у найжахливіших реаліях XX i XXI століть, дослідження його вчення набувають усе більшої актуальності у сфері соціогуманітарних наук.

Питання онтологічної цілісності було порушене Бердяєвим уже у другій його книзі - «Нова релігійна свідомість і громадськість», що з'явилася 1907 року на початковому етапі релігійно-антропологічного, за 108 